April 2013

\title{
Gay and Lesbian Literature in the Classroom: Can Gay Themes Overcome Heteronormativity?
}

April M. Sanders

University of North Texas, aprilsanders@Me.com

Janelle B. Mathis Ph.D.

University of North Texas, janelle.mathis@unt.edu

Follow this and additional works at: https://digitalscholarship.unlv.edu/jpme

\section{Repository Citation}

Sanders, April M. and Mathis, Janelle B. Ph.D. (2013) "Gay and Lesbian Literature in the Classroom: Can Gay Themes Overcome Heteronormativity?," Journal of Praxis in Multicultural Education: Vol. 7: No. 1, Article 6.

DOI: $10.9741 / 2161-2978.1067$

Available at: https://digitalscholarship.unlv.edu/jpme/vol7/iss1/6

This Article is protected by copyright and/or related rights. It has been brought to you by Digital Scholarship@UNLV with permission from the rights-holder(s). You are free to use this Article in any way that is permitted by the copyright and related rights legislation that applies to your use. For other uses you need to obtain permission from the rights-holder(s) directly, unless additional rights are indicated by a Creative Commons license in the record and/ or on the work itself.

This Article has been accepted for inclusion in Journal of Praxis in Multicultural Education by an authorized administrator of Digital Scholarship@UNLV. For more information, please contact digitalscholarship@unlv.edu. 
Historically, lesbian, gay, bisexual, and transgender (LGBT) characters did not exist in the texts read and discussed in classrooms. One reason for the lack of classroom exposure to literature with homosexual themes could be contributed to avid censorship of such books. Daddy's Roommate (1990) by Michael Willhoite was the second most banned/challenged book between 1990-2000, and Heather has Two Mommies (1990) by Leslea Newman ranked ninth as being the most banned/challenged in that decade. During the next decade both titles were not as fiercely contested. Willhoite and Newman's book did not appear on the list of the 100 most banned/challenged books; And Tango Makes Three by Justin Richardson and Peter Parnell was the only book in the top ten contested books with gay and lesbian themes. Even though censorship continues to occur with LGBT books published for children, the books are not listed in the top ten censored books as often as a decade earlier.

In order to fight censorship and prejudice surrounding LGBT literature, young readers as well as teachers and parents must learn how to transform their views of LGBT people. Educational organizations have realized the need for such a change in the classroom and have made a call for action; the National Council of Teachers of English (NCTE) passed a resolution (2007) calling for inclusion of LGBT issues in the classroom in addition to providing guidelines for training teachers on such inclusions. In spite of this resolution calling for inclusion and training, pedagogy in the K-12 educational setting has not typically focused on how to incorporate techniques to help dispel prejudices and strengthen positive identities of gay and lesbian students. Since prejudices do prevail, negative effects were shown to appear in students when classroom discussion of LGBT issues and literature was limited (GLSEN, 2009). In contrast, the identity formation of the LGBT student could possibly form positive roots in LGBT literature and classroom discussion that does focus on LGBT characters and issues. LGBT literature is becoming more available for young readers, and K-12 curriculum should include literature with gay and lesbian themes and/or characters. The question for researchers to investigate has gone beyond whether or not LGBT texts should be included in classrooms to "how these texts might be used in schools" (Blackburn \& Clark, 2011, p. 150). This integration could facilitate an inclusion and/or understanding of the LGBT experience. Pedagogy needs to incorporate techniques to help dispel prejudices and strengthen positive identities of LGBT students to accompany such literature inclusion in the classroom.

In spite of the lack of LGBT literature (both fiction and non-fiction) in classroom reading and discussion, children's and adolescent literature does include such LGBT characters and gay-themed storylines; just because the literature is not being included in classroom reading does not mean it does not exist or is not available for young readers. LGBT literature is available to students, and as a result, teachers and national educational organizations are calling for pedagogy to include LGBT issues. Yet the practice of simply including diverse texts without discussing LGBT issues could cause greater marginalization for students. This type of practice of including LGBT literature without the appropriate environment of discussion creates a context that encourages heteronormativity.

Heteronormativity is the normalizing of one sexual identity by portraying the world as only heterosexual (Nelson, 2009). Watney (1991) better describes such a process as avoiding "any representation that might reveal the actual diversity and complexity of sexual choice" thus normalizing heterosexuality (p. 394). Schools have encouraged the practice of heteronormativity in various ways, and Pinar (1994) calls 
schools a "gender ceremony that compels heterosexuality" (p. 176). Classroom discussions should not avoid topics related to the LGBT characters or themes in texts. In fact, texts do not have to be labeled as LGBT texts to see LGBT themes present. When teaching traditional literature, it is often considered taboo to discuss and analyze LGBT themes or subtexts that could be present in literature. When these subtexts are avoided and not discussed, heteronormativity begins to exist because students "assume that lesbian and gay content is not there, that lesbian and gay students don't exist, that lesbian and gay experience is invisible" (Greenbaum, 1994, p. 71). Greenbaum, an out lesbian faculty member, works to present a balanced view of literature by including such gay subtexts in her discussion of traditional literature. She presented this balanced view while she was still closeted, and she admits that after she came out she was able to begin to include LGBT literature to her classroom reading.

When choosing LGBT texts to include in classroom curriculum, books should be reviewed for content and themes that require acknowledgement and conversation about LGBT issues. In order to combat heteronormativity, quality texts must be chosen that cannot be "sanitized," meaning the LGBT themes and issues are avoided. The study of quality LGBT texts would crumble if such significant themes and issues were ignored and not discussed. Reading these texts should not be for the sole purpose of adding a diverse voice to the mix of texts provided to the young readers. Simply because a student reads a book with LGBT characters does not mean that student will gain a sensitivity or understanding of LGBT people. A realization must occur that adding these voices in literature could provide an opportunity to understand the LGBT identity. The voices should not be put aside by the practice of heteronormativity. In quality texts, the LGBT themes must be so deeply embedded in the development of the story that teachers would not even have an option to practice heteronormativity. Since such a need exists, do quality LGBT texts exist in children's and adolescent literature that would develop discussion about pertinent LGBT characters and issues? As LGBT literature begins to be included in the classroom, importance should be placed on using books containing themes about LGBT characters and experiences. An analysis of quality LGBT books could help educators when beginning to incorporate diversity into the classroom and avoid heteronormativity, which can undermine the positive aspects of LGBT literature being used in the classroom.

This inquiry examined a range of children's and adolescent books that could be used in classroom discussions to develop an understanding of LGBT themes and characters. The analysis of these books viewed emerging themes regarding LGBT characters and experiences. The findings from this study assessed whether the texts are saturated with LGBT themes and characters to the point that teachers and students could avoid the LGBT factors while reading.

The guiding questions for the study were:

1. What common themes are present in LGBT children's and adolescent literature?

2. Are the common themes indigenous to the LGBT experience, or are the themes reflections of the common experience of all children and teens?

Review of Literature

\section{Evolution of Queer Studies}


Prior to the 1940s, homosexuality was regarded as deviant behavior, even as a contagious disease. Schools sometimes expelled students and often fired teachers who were either suspected or found to be homosexual. These targeted students and teachers usually kept a very low profile about their homosexuality and the reason for being expelled, which resulted in a lack of studies about homosexual students' experiences or identities (Tierney \& Dilley, 1998). During the 1950s, homosexuality was still perceived as a disease, but there was interest in treating the disease instead of viewing it as a personality disorder. The American Psychiatric Association listed homosexuality as a disease until 1973 (Dilley, 2002).

Once homosexuality was removed from the list of mental disorders, then a visible quest for civil rights began. With increasing visibility came the development of studies focusing on identity. Some areas in the literature still need more identity research such as with queer students of color or queer faculty members, although there have been some recent contributions. For instance, Abes (2009) and Renn (2010) use queer identity development to help develop curriculum and support student learning. One significant gap in the literature is the connection between texts and sexual identity (Moje \& MuQaribu, 2003). This gap in the literature should be explored to discover the link between sexual identification and texts as well as provide pedagogical models for teachers on how to conduct discussions regarding such a link within these texts with their students. By providing such models, the practice of heteronormativity can be avoided.

\section{Heteronormativity}

In queer theory, the term queer does not refer specifically to gay or lesbian identity. Instead, the theory claims that empirical knowledge is learned within the schema of the heterosexual culture; ideas are formed within the context of the heterosexual culture as normal and homosexuality is considered an abnormal alternative (Nelson, 2009). Queer theory suggests that "heterosexuality has meaning only in relation to homosexuality" and "the coherence of the former idea is predicated on the exclusion, repression, and repudiation of the latter" (Pinar, 1998, p. 9). Martino (2009) explains that queer theory is focusing on the understanding of how systems establish what is normal which helps create identity. The heterosexual system is established as normal. Those who are homosexual and forming identities are influenced because they are deemed outside the established normal; the sexual identity conveyed to LGBT people as normal is heterosexuality. When this situation occurs for a LGBT person, s/he begins to internalize that the sexuality they naturally want to identify with is considered in opposition to the norm. They could form identities based on believing one component of their identity homosexuality - is not normal. Additionally, identity formation for heterosexuals would have a reinforced foundation in being considered normal and viewing homosexuality as opposed to such a norm.

One aspect of heteronormativity is silence, and silence does not give way to neutrality. Silencing can be done through two processes: systematic exclusion and systematic inclusion (Friend, 1993). Systematic exclusion can be defined as "ignoring or denying the presence of lesbian, gay, and bisexual people (Friend, 1993, p. 212). Such silence does not always have to come from heterosexual individuals. When LGBT people remain silent about their relationships and lives, they convey an LGBT identity as something of which to feel shame (DePalma \& Atkison, 2009). Additionally, when teachers are silent about LGBT themes in texts, the same inference about shame is given to students. Along with silence, teachers imply negative connotations about LGBT 
identities when they demonstrate they are not comfortable saying words like gay and lesbian (DePalma \& Atkison, 2009). Yet, the way to oppose heternormativity is to be open when discussing LGBT themes with students so that they can form their own truth (Nelson, 2009). Hoffman (1993) describes such absence of discussion and acknowledgement as a "conspiracy of silence we have all entered into" with a result that "can only damage their [students] chances of emerging whole from their school years" (p. $56)$.

Friend (1993) explains systematic inclusions as "when discussions regarding homosexuality do occur, they are consistently placed in a negative context" (p. 215). One example of systematic inclusion at work is with the 1995 World Book encyclopedia. Evans (1999) points out that two pages in the text are devoted to homosexuality while no mention is made in the text of heterosexuality. The implication of leaving out an explanation of heterosexuality reinforces that it is the norm because "no definition is needed because heterosexuality is the assumed way of being" (Evans, 1999, p. 9). The silence in classrooms when discussing texts or issues related to LGBT situations and the lack of materials containing LGBT themes are examples of how heteronormativity works to create an environment where only one sexual identity - heterosexuality - is considered normal.

\section{Unmasking Heteronormativity}

The way to combat heteronormativity is not just about including texts with gay characters. Inclusion alone is not the solution. Sumara, Davis, and Iftody (2006) investigated what happened in one classroom when students read the novel Stitches in an attempt to expose students to a gay character. The main character suffers abuse through bullying because he is gay, but the class discussions center only on the issue of bullying. Even though the bullying was directly related to the character identifying as gay, the students never discussed homophobia as a cause for the abuse. Instead, the students discussed the perils of bullying in a general sense for all students. Stereotypes about LGBT people were actually reinforced by the reading because the focus was not provided for discussing the character's gay identity or the issue of homophobia. The researchers concluded teachers should provide opportunities for students "to analyze the diversity of personal readings within a safe and intellectually supportive context" (p. 65). Heteronormative constructions were maintained even though a gay character was included in the classroom literature because the teacher never facilitated a discussion about the character having a gay identity.

Classroom discussion must include talking about LGBT themes; if not, silence regarding LGBT characters or themes in a text only reinforces the idea that homosexuality should be kept hidden. Martino (2009) conducted a study using interactive theatre as an attempt to include gay themed discussions and deal with violence connected to homophobia. In interactive theatre, the play is performed a second time, and the audience has the ability to stop the action and intervene. Martino observed that the drama teacher was very skilled in this method. The play was about two adolescent boys who are friends. Matthew is a stereotypical jock, and Steven is a quiet bystander who eventually reveals he is gay. The pedagogical context used with the second interactive version of the play directs students to intervene on behalf of those experiencing violence. Another character is presented in the play who is a female involved in an abusive relationship with a male. The students were willing to come to the aid of the female character experiencing violence at the hands of her boyfriend, but the 
same students laughed uncomfortably during Steven's coming out scene. Students were not willing to defend Steven and sat silent when Matthew called Steven a faggot. A discussion should have resulted about these reactions to the gay character. The teacher facilitating the theatre experience needed to have some pedagogical direction to advise students at certain points in the play. For example, direction is needed when students laugh at Steven's coming out. Martino notes that the theatre teacher did not address the laughter or discuss Steven's disclosure of being gay. By allowing this behavior to exist without any discussion or discovery into the character's gay identity, heternormativity encourages the silencing of the gay character's voice.

The inclusion of the gay character in the studies discussed (Sumara, Davis, and Iftody, 2006; Martino, 2009) only reinforces the norm as heterosexual. Martino argues that one implication of this activity is the weakness of simply including a gay character as a way of solving homophobia. An additional implication could be that adding literature with a gay theme or gay character to classroom reading is not enough; pedagogy should include ways of discovering how heternormativity has taught that such characters are not part of the norm. Sumara, Davis, and Iftody (2006) explain that literature plays a crucial role in the formation of identity, and experiences with literature should be included in the classroom to help students gain a better understanding of personal identity. Just as students begin to identify and understand characters in the text, they also reshape their own understandings of self. Because literature plays a role in identity formation, the teaching of literature with gay themes and characters must have a pedagogical context accompanying the text. Otherwise, inclusion of diverse texts is done only for the sake of a surface-level inclusion. When pedagogy and training is not available for teachers, the resulting tendency is to reinforce - through heteronormativity - a deeper stigma about homosexuality through silence regarding LGBT characters and issues or demonstrating a clear uncomfortable stance when discussing such issues. By excluding homosexuality, the heterosexual perspective remains dominant as the norm, and this level of exclusion results in a form of bigotry (Nelson, 2009). Blinick (1994) looked at history textbooks that were available for possible adoption and noted the absence of LGBT people. Additionally, LGBT people were not even identified as such: "the homosexuality of James Baldwin and Gertrude Stein is not mentioned, despite the fact that both were openly gay people whose sexual orientation strongly influenced their work" (p. 146). The "hidden curricula" or rather what is not said or discussed with students can shape students just as effectively as the overt curricula (Auerbach \& Burgess, 1985).

\section{Perspective while Reading LGBT Text}

LGBT literature is not simply intended for heterosexual readers to gain an understanding of LGBT people; the texts are also a way for LGBT readers to connect with such characters and see aspects of their own experiences in the reading. Whether the reader identifies as LGBT or not, the text can provide insight for the reader. Borrowing from Bishop, (1992) mirrors and windows are used as metaphors for literature that invites readers to view themselves and view the world, thus LGBT literature can serve both homosexual and heterosexual readers. Mirrors would be used to describe how the LGBT readers look at the text because they could see aspects of their own story in the characters and themes present, yet heterosexual readers would be looking through a window to view a life and identity with which they are not intimately familiar.

\section{Stereotypes in Literature}


LGBT readers do share the experience of being gay, but the details of that experience are varied. Sumara and Davis (1999) conducted a research project focusing on a group of gay and lesbian teachers who were given readings to discuss. The prediction was that the responses would be similar among the group participants since they were all reading the same text and all identified as LGBT. Surprisingly, the participants did not have the same responses to the text. Even though several gay men in the group talked about how the entire group should be united in their view since they were all gay, the women in the group noticed that several of the men began demonstrating a sexist response to the literature. One particular text was about a gay male experience; however, the men in the group had less identification with that character. One male participant commented: "I can't identify with what this character finds sexually arousing, even though we both call ourselves gay" (p. 195). The group grew cognizant of how differently they each identified with the literature even though they all had the common experience of being gay. Because the responses varied as the group delved deeper into the literature, Sumara and Davis discovered there was no "quintessential queer identity" because "lives are not lived as stereotypes or categories" (p. 196).

Suggestions for curriculum development stemming from this study are centered on how differences among people and categories of people could be interpreted and better understood. Therefore, educators should restructure curriculum to examine how marginalization can be avoided. Stereotypical gay and lesbian characters are ineffective in producing a true identification with readers because those types of characters reinforce the practice of heteronormativity by showing characters who are opposed to the norm. Texts should be used portraying the variety of LGBT characters that actually exist. By achieving a level of variety in the texts, educators can begin to develop and incorporate pedagogy that will combat heteronormativity.

\section{Examining Gay and Lesbian Literature}

Hoffman (1993) found some surprising results when he used an LGBT play, Torch Song Trilogy, in his classroom with students. He had worked with the text in a professional course with fellow teachers and pre-service teachers, and at the end of the reading, his fellow classmates expressed dismay about how this text filled with LGBT characters and themes could not be taught in a high school setting. Hoffman returned to his high school classroom and decided to prove them wrong. He prepared students by telling them they could have an alternative assignment if they or their parents had objections. Students were expected to keep journals as they read, and most of the entries contained direct responses to the text. After analyzing the journal entries, Hoffman found that they "were full of indications that reading the play had changed students' perceptions and attitudes" (p. 57). Even though his colleagues believed teaching this LGBT play would be too explosive for the high school classroom, Hoffman found that students were able to read the play and discuss LGBT themes and characters in such a way that resulted in enlightenment about a topic usually not discussed.

Three previous studies that analyzed LGBT literature found themes that could lead to marginalization (see Table 1). These studies were similar in they all analyzed LGBT adult literature and discussed how the themes and characters presented in the literature could have implications for how LGBT readers would themselves as well as how heterosexual readers would view LGBT people and issues. Hanckel and Cunningham (1976) identified four novels containing queer themes. In spite of the 
groundbreaking nature of these novels, they all contained gay male characters who died. Readers were given the impression that homosexuality was only a phase leading to demise. Wilson (1984) analyzes seven books depicting LGBT themes and finds four of the seven containing positive outcomes that suggest a need for more positive characterization of LGBT characters. Norton and Ware (2004) look at a sampling of seven adult books with LGBT themes that show positive and realistic characters. The novels, which contain a mix of male and female characters, trace the development and resolution of the characters' identity crisis with being gay. This study's implications detail how literature can give voice to the silence surrounding homophobia.

Table 1

Previous Studies on LGBT Texts

Hanckel \& Cunningham (1976)

\begin{tabular}{lll}
\hline Title & Author & Year Published \\
\hline I'll Get There. It Better Be Worth & John Donovan & 1969 \\
the Trip. & Isabelle Holland & 1972 \\
The Man without a Face & Lynn Hall & 1972 \\
Sticks and Stones & Sandra Scoppettone & 1974 \\
Trying Hard to Hear You & & \\
\hline
\end{tabular}

\section{Wilson (1984)}

\begin{tabular}{lll}
\hline Title & Author & Year Published \\
\hline Young, Gay, and Proud & Sasha Alyson, Ed. & 1980 \\
Dance on My Grave & Aidan Chambers & 1982 \\
Independence Day & B.A. Ecker & 1983 \\
Reflections of a Rock Lobster & Aaron Fricke & 1981 \\
Annie on My Mind & Nancy Garden & 1982 \\
One Teenager in Ten & Ann Heron, Ed. & 1983 \\
A Boy's Own Story & Edmund White & 1982
\end{tabular}

\section{Norton \& Vare (2004)}

\begin{tabular}{lll}
\hline Title & Author & Year Published \\
\hline Geography Club & Brent Hartinger & 2003 \\
Gravel Queen & Tea Benduhn & 2003 \\
How I Fell in Love and Learned to & Jon Ripslinger & 2003 \\
Shoot Free Throws & Julie Anne Peters & 2003 \\
Keeping You a Secret & Lauren Myracle & 2003 \\
Kissing Kate & Glen Huser & 2003 \\
Stitches & Carol Plum-Ucci & 2002 \\
What Happened to Lani Garver & & \\
\hline
\end{tabular}

\section{Methodology}

The chosen texts for this study included the winner of the 2010 Stonewall Book Award - Children's and Young Adult Literature Award and Stonewall Honor books in 
Children and Young Adult (see Table 2). These books range from young adult fiction and non-fiction to illustrated children's books. When the American Library Association's Stonewall Book Award committee began selecting books for the award in the early 1970 s, they only had a small selection of choice; however by 1995 , the committee was selecting winners from over 800 titles. This award was the first given to LGBT books thus having the longest record of selection compared to other LGBT book awards. The award, which is given to an exceptional book about the gay, lesbian, bisexual, or transgender experience, included a new category in 2010 for children's and young adult literature (ALA, 2009). Awards are inclusive of two categories: literature and nonfiction. The literature category includes novels, short stories, poetry, and drama. The nonfiction category includes biography, history, criticism, reference works, fine arts, and other traditional nonfiction genres. The Stonewall Book Awards Committee is comprised equally of female and male members and can have no fewer than six and no more than 14 members. Committee members are selected to also represent a variety of geographical regions of the United States, racial and ethnic groups, and types of libraries. The winner and honor books of the Stonewall Book Award were chosen for this study based on the longevity of the award, the vastness of genre considered for the award, and the variety of committee members judging the books.

Table 2

Chosen Texts for Study

\begin{tabular}{|c|c|c|c|}
\hline $\begin{array}{l}2010 \text { Stonewall Book } \\
\text { Award - Children's } \\
\text { and Young Adult }\end{array}$ & Title & Author & $\begin{array}{l}\text { Year } \\
\text { Published }\end{array}$ \\
\hline Award Winner & $\begin{array}{l}\text { The Vast Fields of } \\
\text { Ordinary }\end{array}$ & Nick Burd & 2009 \\
\hline Honor Book & 10,000 Dresses & $\begin{array}{l}\text { Marcus Ewert } \\
\text { Rex } \\
\text { (illustrator) }\end{array}$ & 2009 \\
\hline Honor Book & Daddy, Papa, and Me & $\begin{array}{l}\text { Leslea Newman } \\
\text { Carol Thompson } \\
\text { (illustrator) }\end{array}$ & 2009 \\
\hline Honor Book & $\begin{array}{l}\text { Gay America: Struggle } \\
\text { for Equality }\end{array}$ & Linas Alsenas & 2009 \\
\hline Honor Book & Mommy, Mama, and Me & $\begin{array}{l}\text { Leslea Newman } \\
\text { Carol Thompson } \\
\text { (illustrator) }\end{array}$ & 2009 \\
\hline Honor Book & Sprout & Dale Peck & 2009 \\
\hline
\end{tabular}

Using the constant-comparative method (Glaser \& Strauss, 1967), each text was read twice before making a list of emerging themes. During those initial readings, particular attention was focused on any prominent themes emerging from the texts without regard to a relation to LGBT issues. Each text was then read a third time to code specific references related to each theme. References were also coded to include the particular characters (both main and supporting characters) and events involved in each reference. As coded data were added to each theme, the parameters of each theme were 
continually analyzed. The list of themes was then reduced to those with the most data supplied from the texts.

The themes were then divided into a group of themes relating only to the children's literature selections and a group of themes relating only to the adolescent/young adult literature selections. After the two groups of themes were identified, the events listed in each category were reviewed and an overarching theme emerged for each group (see Figures 1 and 2). 
Figure 1

Adolescent/Young Adult Literature Themes

The Vast Fields of Ordinary $\begin{aligned} & \text { Gay America: Struggle for Sprout } \\ & \text { Equality }\end{aligned}$

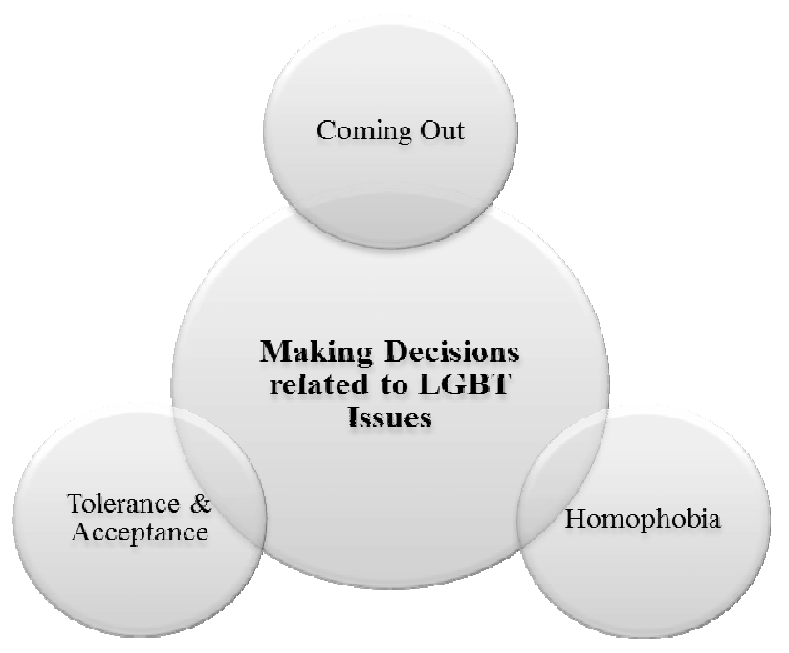

Figure 2

Children's Literature Themes

10,000 Dresses Daddy, Papa, and Me Mommy, Mama, and Me

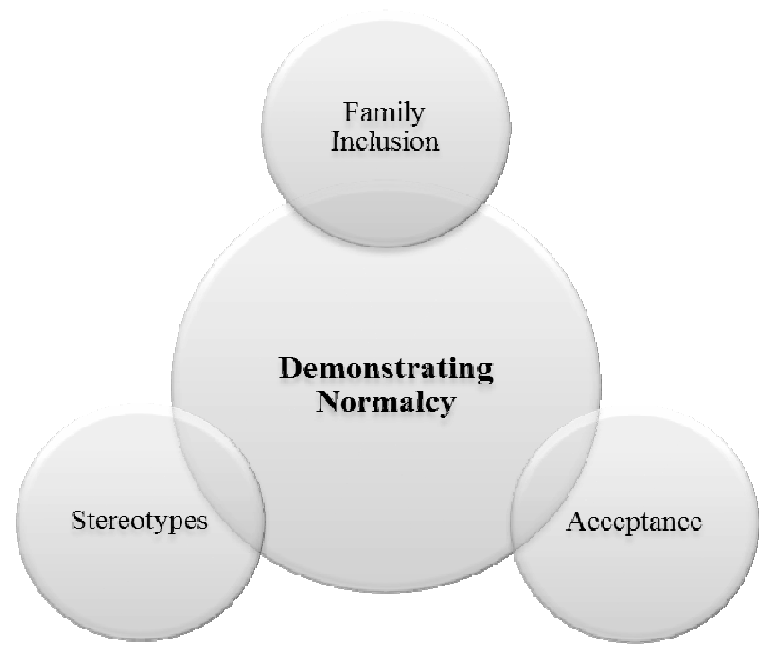

\section{Authenticity of Experience}


In connection to the content study, an online search was conducted to find the sexual orientation of each book's author and illustrator. The sexual orientation information as shown in Table 3 can be used as additional consideration of authenticity when examining the themes present in the texts.

Table 3

Sexual Orientation of Authors and Illustrators

\begin{tabular}{|c|c|c|}
\hline Title & Author & Sexual Orientation \\
\hline The Vast Fields of Ordinary & \multirow{4}{*}{$\begin{array}{l}\text { Nick Burd } \\
\text { Marcus Ewert } \\
\text { Rex Ray (illustrator) } \\
\text { Leslea Newman }\end{array}$} & Gay \\
\hline 10000 Dresses & & Gay \\
\hline 10,000 Dresses & & Unknown \\
\hline \multirow[b]{2}{*}{ Daddy, Papa, and Me } & & Lesbian \\
\hline & $\begin{array}{l}\text { Carol Thompson } \\
\text { (illustrator) }\end{array}$ & Heterosexual \\
\hline $\begin{array}{l}\text { Gay America: Struggle for } \\
\text { Equality }\end{array}$ & Linas Alsenas & Gay \\
\hline & \multirow{3}{*}{$\begin{array}{l}\text { Leslea Newman } \\
\text { Carol Thompson } \\
\text { (illustrator) } \\
\text { Dale Peck }\end{array}$} & Lesbian \\
\hline Mommy, Mama, and Me & & $\begin{array}{l}\text { Lesoran } \\
\text { Heterosexual }\end{array}$ \\
\hline Sprout & & Gay \\
\hline
\end{tabular}

\section{Themes}

The themes that emerged from data in this study were divided into two categories based on the reading level of the books: adolescent/young adult selections and children's literature selections. Both sets of themes also related to a larger theme for each category. The first category deals with themes in adolescent/YA literature centering on making decisions related to LGBT issues. The second category of themes comes from the children's literature and focuses on demonstrating normalcy in everyday life situations. The normalcy in everyday life situations deals with activities that are part of a daily routine (for example: family meals, playing ball, parents reading a book to a child).

\section{Adolescent/Young Adult Literature Selections}

\section{Coming Out}

Coming out is when an LGBT person goes through the process of telling people in his/her life about his/her sexuality. This process can include talking about personal sexuality with friends and family as well as on a larger scale within one's community. Gay America (Alsenas, 2008) gives considerable attention to how many LGBT people were closeted throughout history, and when they did come out, they suffered. Alsenas (2008) discusses the celebrities who decided to come out, including the famous coming out event of Ellen DeGeneres.

In the Vast Fields of Ordinary (Burd, 2009), the main character, Dade, practices coming out several times, and at one point, he even comes out to the ceiling fan above his bed. When Dade is asked if he is gay, he does not know how to respond even though he has had practice sessions. Dade begins the true coming out process when his friend, Lucy, asks him if he is gay and makes him answer. He worries about how he will come out to his parents and finally does tell them he is gay, and Lucy congratulates him 
because "that's a big deal" (p. 193). Throughout the novel, the coming out process is a constant focus. The story even has Dade coming out to his college roommate in the final pages of the novel.

Sprout in Sprout (Peck, 2009) comes out to his high school English teacher, Ms. Miller, only to have her advise him to hide his sexuality while in high school because she is worried about possible repercussions. He considers her advice throughout the book as he decides whether or not to write about being gay in a state writing contest. Again, Ms. Miller has warned him against writing about the topic of being gay for fear the conservative judges will not grade his essay fairly. He wonders what it would be like for him to have a boyfriend someday and be open about his sexuality with his friends and family. Sprout does deal with the turmoil of telling his father he is gay, and when he comes out to his father, his father becomes very angry and finally ends his rant with an apology for not providing Sprout with a mother figure implying he has failed Sprout as a parent. The father implies that his son's being gay is due to the home context rather than other personal factors.

\section{Tolerance and Acceptance}

Gay America (Alsenas, 2008) has an entire chapter devoted to tolerance and acceptance titled "Good Times...\& Bad Times" which tells of the dark times LGBT people dealt with during 1910 - 1939. A later chapter in the book gives more updated accounts of tolerance and acceptance for LGBT people with explanations of how Massachusetts granted LGBT couples the right to marry in 2004 signaling a gain in acceptance, but Alsenas (2008) goes on to explain that a SWAT team was assigned to guard the first people standing in line to marry. Additionally, the high-profile killings of Matthew Shepard, Barry Winchell, and Brandon Teena due to their LGBT identity is discussed.

Dade in Vast Fields of Ordinary (Burd, 2009) deals with issues of tolerance and acceptance regarding being gay in much the same way Sprout in Sprout (Peck, 2009) deals with the same issues. Both characters have parents who have strong negative reactions when finding out their son is gay. The characters must live through the parents' process of tolerating their son's gay identity before beginning to accept their child's sexuality. This process includes crying and becoming angry when first finding out and uncomfortable encounters when meeting a boyfriend. Eventually, the parents do achieve a level of acceptance; Dade talks about receiving a check from his mother one day after going to college where she has included a note to take a nice boy out to dinner.

The characters are also consumed with those in their environment tolerating or accepting them and their sexuality. Sprout moves from Long Island, New York, and comments that he was not unique there, but he believes he is "marked" in Kansas (Peck, 2009, p. 65). Sprout even details several facts about how Kansas is not tolerant of LGBT issues. Dade deals with being an outcast for most of his high school career but finds comfort in having a college roommate who accepts him for being gay: "Four weeks later he was trying to set me up with a guy in his bio class. By second semester we were like brothers" (Burd, 2009, p. 306).

\section{Homophobia}

Homophobia is a reoccurring theme throughout all the adolescent/young adult books. Gay America (Alsenas, 2008) details the history of homophobia by giving the beginning medical term ("inversion") used for describing LGBT people. Details of 
homophobia are traced back to the Victorian Era, and the acceptance found in Paris for LGBT Americans during the 1920s is shown in sharp contradiction to the bigotry found in the United States at that time (Alsenas, 2008). The characters in both Sprout (Peck, 2009) and Vast Fields of Ordinary (Burd, 2009) must consistently deal with negative comments and remarks. Dade is called faggot and homo numerous times by his classmates. Sprout is told he is from Long Gayland instead of Long Island. Sprout even suffers humiliation when a classmate put a cap over his face when they have sex so that the other boy does not have to "look at what we [they] are doing" (Peck, 2009, p. 93). They deal with homophobia from the adults in their lives too. Sprout points out to Ms. Miller that she immediately asks him about his sex life when she finds out he is gay, and she would not do that with her heterosexual students. When Dade invites his boyfriend to dinner to meet his parents, his dad has to leave the table because he admits he cannot tolerate eating dinner with his son's boyfriend.

\section{Decisions Related to LGBT Issues}

The adolescent/young adult selections did display specific references within the themes to decision-making related to LGBT issues. When coming out, decisions must be made about when and if and how to come out and to whom. When dealing with homophobia, decisions have to be made regarding how to deal with the prejudice confront it or ignore it. Within the theme of tolerance and acceptance, the heterosexual people within the stories must make a decision to either tolerate or accept the LGBT people. In turn, the LGBT people must deal with that decision regarding tolerance or acceptance. Compounded with the harassment issue can be the lack of support and resources available for LGBT people, and LGBT students "from poor and rural communities are acutely disadvantaged in obtaining resources, finding allies, and integrating into school culture" (Kim, Sheridan, \& Holcomb, 2009). Resources are severely needed for adolescent students to develop appropriately in a social realm. When LGBT students reach adolescence and begin to work through natural stages of development, they are at a disadvantage compared to their heterosexual peers. Heterosexual students have fairly established roadmaps to follow for social development stages, but LGBT students do not have similar support (Pascoe, 2007). The themes presented in the YA books in the study can help overcome heteronormativity because they openly discuss specific issues of tolerance and acceptance as well as coming out which LGBT adolescents will encounter. By portraying these issues through characters in the YA novels, readers begin to understand the evolution that LGBT adolescents go through, and understanding can lead to overcoming the silence that is the fabric of heteronormativity.

\section{Children's Literature Selections}

\section{Acceptance}

In both Mommy, Mama, and Me (Newman, 2009) and Daddy, Papa, and Me (Newman, 2009), the child in each story is shown asking parents to play and engages happily with both homosexual parents in routine activities, such as reading, bath time, and eating a meal together. The child in Daddy, Papa, and Me tucks both parents in and kisses them goodnight when they fall asleep together on the couch, and the child is shown in the illustrations as running happily toward both parents to join them. Acceptance of 
the family interacting together in a happy manner is demonstrated on almost every page of both books. Acceptance is also central to 10,000 Dresses (Ewert, 2009), but the theme is handled much differently than the other two children's books. Acceptance is what Bailey is seeking when s/he (a biological male child identifying as female) seeks approval from each of her family members who only turn the child away with negative remarks.

\section{Family Inclusion}

The family as a cohesive group is demonstrated in both of Newman's books (2009). Daddy and Papa have a tea party together with the child, and all play with paper airplanes. When the two fathers fall asleep on the couch together at the end of the story, the child kisses them both ending on a note of cohesion. Mommy and Mama are shown happily sharing a meal together with their child and all reading together. The final scene of the book shows the two mothers putting the child to bed. Bailey in 10,000 Dresses (Ewert, 2009) goes to each and every member of the family seeking inclusion by sharing the dream of beautiful dresses but is turned away and resorts to finding an inclusive environment with someone outside the family.

\section{Stereotypes}

Ewert (2009) reinforces the hurt the main character Bailey feels as each family member says, "boys don't wear dresses" (p. 9, 15). Bailey's brother is particularly hurtful by exclaiming, "You dream about DRESSES, Bailey? That's gross. You're a boy" (p. 22). While Ewert's picture book shows how the stereotype of what is acceptable for boys and girls to wear is hurtful, the two picture books by Newman (2009) demonstrate that stereotypes do not have to exist with LGBT couples. In Mommy, Mama, and Me (Newman, 2009), the mothers share both traditionally female and male tasks. They both help the child with preparing meals, playing with the child and carrying her on their back in a playful manner, helping with hygiene (bathing, combing hair, etc...), and teaching the child to read. Similarly Daddy, Papa, and Me (Newman, 2009) portrays the two fathers mixing roles that are stereotypically assigned to either male or female parents. Daddy wears a masculine crown but also teaches the child how to sew. Papa bakes a pie but also teaches the child how to throw a ball.

\section{Demonstrating Normalcy}

The children's literature selections were saturated with data that pointed to the overarching theme of demonstrating normalcy in everyday life situations including LGBT people. The Newman books both portray families with LGBT parents who function just like heterosexual parents by doing tasks and maintaining responsibilities just like any other parent. Throughout all the children's literature selections, the data revealed that the three themes were constantly woven into the stories. The child in each of the books only demonstrates a happy and content disposition from having LGBT parents; the situation is presented as normal instead of an anomaly from heterosexual parenting. These themes would also be seen to some extent in children's literature that does not contain characters or story content related to LGBT issues, but these themes of inclusion, acceptance, and stereotypes are viewed as having particular importance for LGBT people. Ewert's (2009) book takes a different turn by showing a child constantly looking for normalcy within the family structure. The child wants to share dreams and gain support from family members but only encounters resistance to maintain a 
stereotype of what is considered to be normal. Since LGBT readers are accustomed to fighting for a level of acceptance for having families and daily routines that should be considered normal, then their reading about these families in the children's books who are demonstrating such normal behavior while also being LGBT families is reassuring. Additionally, heteronormativity can be combated with having these themes present in the children's books because heterosexual readers could read these texts and realize that what they consider normal family routines do not have to only include heterosexual people; LGBT people can have families and interact with one another and be considered normal.

\section{Implications and Recommendations}

Through this content analysis, themes revolving around LGBT issues and experiences are shown to saturate these award-winning texts. This saturation of LGBT themes within these books at various reading levels demonstrated that quality texts do exist. Using such texts as described here can help combat heteronormativity because the books are so centrally focused on LGBT themes that those themes cannot be ignored during a classroom discussion. If the themes of these books were ignored during discussion, the entire structure of the story and character development could not be adequately addressed. By dissecting the themes and showing examples within LGBT texts in this study, teachers can begin to understand what to look for in other LGBT texts that would like to include in their classroom reading. A logical next step would be to take the emerging themes from the study and incorporate them into pedagogy that could be used in classrooms to discuss texts with LGBT characters and themes. Training for educators about how to best talk with students regarding these issues must begin with teaching educators about recurring themes in the texts as well as how to appropriately discuss them in a classroom environment.

Content analysis on specific aspects of the LGBT community needs to be provided to enlarge the understanding of LGBT people. For example, further analysis could center on a specific component of the LGBT community, such as lesbians or transgender people, to provide an in-depth analysis of that one aspect of the community. Further research needs to explore how to use texts with a saturation of LGBT themes as a foundation for discussion within the classroom so that the discussion does not adhere to the bigotry of heteronormativity. Research needs to also explore student responses and reactions to texts saturated with LGBT themes to help understand identity development. Both LGBT students and heterosexual students should be able to witness and understand LGBT experiences through classroom texts, and further research about techniques for such discussions and pedagogy could help teachers overcome the prejudice that is alive and well in their classrooms.

\section{Literature Cited}

Alsenas, L. (2008). Gay America: Struggle for equality. New York: Amulet Books. Burd, N. (2009). The vast fields of ordinary. New York: Dial Books.

Ewert, M. (2009). 10,000 dresses. New York: Seven Stories.

Newman, L. (2009). Daddy, pappa, and me. Berkeley: Tricycle Press. Newman, L. (2009). Mommy, moma, and me. Berkeley: Tricycle Press. Peck, D. (2009). Sprout. New York: Bloomsbury.

\section{References}


Abes, E.S. (2009). Theoretical borderlands: Using multiple theoretical perspectives to challenge inequitable power structures in student development theory. Journal of College Students Development, 50, 141-156.

Auerbach, E.R., \& Burgess, D. (1985). The hidden curriculum in survival ESL. TESOL Quarterly, 19(3), 475-495.

Bishop, R.S. (1992). Multicultural literature for children: Making informed choices. In V. Harris (Ed.), Teaching multicultural literature in grades $K-8$ (p. 37-54). Norwood, MA: Christopher-Gordon.

Blackburn, M.V. \& Clark, C.T. (2011). Becoming readers of literature with LGBT themes: In and out of classrooms. In S.A. Wolf, K. Coats, P. Enciso, \& C.A. Jenkins (Eds.) Handbook of Research on Children's and Young Adult Literature (p. 148-163). New York: Routledge.

Blinick, B. (1994). Out in the curriculum, out in the classroom: Teaching history and organizing for change. In L. Garber (Ed.), Titling the tower (p. 142-159). New York: Routledge.

"By Decade," American Library Association, May 29, 2007. http://www.ala.org/ala/issuesadvocacy/banned/frequentlychallenged/challengedby decade/index.cfm (Accessed April 14, 2010). Document ID: 388244

DePalma, R., \& Atkinson, E. (Ed.). (2009). Interrogating heteronormativity in primary schools. Trent, UK: Trentham Books.

Dilley, P. (2002). $20^{\text {th }}$ century postsecondary practices and policies to control gay students. Review of Higher Education, 25, 409-431.

Evans, K. (1999). “Are you married?”: Examining heteronormativity in schools. Multicultural Perspectives, 1(3), 7-13.

Friend, R.A. (1993). Choices not closets: Heterosexism and homophobia in schools. In L.Weiss \& M. Fine (Eds.), Beyond silenced voices: Class, race and gender in the United States (p. 209-235). New York: State University of New York Press.

Gay, Lesbian, and Straight Education Network (2009). The experiences of lesbian, gay, bisexual and transgender middle school students (GLSEN Research Brief). New York: Gay, Lesbian and Straight Education Network.

Glaser, B. G., \& Strauss, A. L. (1967). The discovery of grounded theory: Strategies of qualitative research. Chicago: Aldine Publishing Company.

Greenbaum, V. (1994). Literature out of the closet: Bringing gay and lesbian texts and subtexts out in high school English. The English Journal, 83(5), 71-74.

Hanckel, F., \& Cunningham, J. (1976). Can young gays find happiness in YA books? 
Wilson Library Bulletin, 50(7), 528-534.

"History," American Library Association, September 09, 2009.

http://www.ala.org/ala/mgrps/rts/glbtrt/stonewall/history/index.cfm (Accessed April 14, 2010). Document ID: 558479

Hoffman, M. (1993). Teaching "Torch Song": Gay literature in the classroom. The English Journal, 82(5), 55-58.

Kim, R., Sheridan, D., \& Holcomb, S. (2009). A report on the status of gay, lesbian, bisexual, and transgender people in education: Stepping out of the closet, into the light. National Education Association. Retrieved March 25, 2011, from http://www.nea.org/assets/docs/glbtstatus09.pdf

Martino, W. (2009). Literacy issues and GLBTQ youth. In L. Christenbury, R. Bomer, \& P. Smagorinsky (Eds.), Handbook of adolescent literacy research (pp. 386399). New York: The Guilford Press.

Moje, E.B., \& MuQaribu, M. (2003). Literacy and sexual identity. Journal of Adolescent and Adult Literacy, 47, 204-208.

National Council of Teachers of English. (2007). Resolution on strengthening teacher knowledge of lesbian, gay, bisexual, and transgender (LGBT) issues. http://www.ncte.org/positions/statements/teacherknowledgelgbt

Nelson, C.D. (2009). Sexual identities in English language education. New York: Routledge.

Newman, L. (1990). Heather has two mommies. New York: Alyson Publications.

Norton, T.L., \& Vare, J.W. (2004). Literature for today's gay and lesbian teens: Subverting the culture of silence. English Journal, 94(2), 65-69.

Pascoe, C.J. (2007). Dude you're a fag: Masculinity and sexuality in high school. Berkely, CA: University of California Press.

Pinar, W. (1998). Introduction in: W. Pinar (Ed.) Queer theory in education. London: Lawrence Erlbaum.

Pinar, W. (1994). Autobiography, politics, and sexuality: Essays in curriculum theory, 1972-1992. New York: Lang.

Renn, K.A. (2010). LGBT and queer research in higher education: The state and status of the field. Educational Researcher, 39(2), 132-141.

Richardson, J., \& Parnell, P. (2005). And Tango makes three. New York: Simon \& Schuster. 
Sumara, D., \& Davis, B. (1999). Interrupting heteronormativity: Toward a queer curriculum theory. Curriculum Inquiry, 29(2), 191-208.

Sumara, D., Davis, B., \& Iftody, T. (2006). Normalizing literary responses in the teacher education classroom. Changing English, 13, 55-67.

Tierney, W.G., \& Dilley, P. (1998). Constructing knowledge: Educational research and gay and lesbian studies. In W.F. Pinar (Ed.), Queer theory in education (pp. 4972). New York: Routledge.

Watney, S. (1991). School's out. In D. Fuss (Ed.), Inside/Out: Lesbian theories/gay theories (pp. 387-401). New York: Routledge.

Willhoite, Michael. (1994). Daddy's roommate. New York: Alyson Publications.

Wilson, D.E. (1984). The Open library: YA books for gay teens. English Journal, 73(7), 60-63. 